\title{
Prospects for the Use of Whey for Polyhydroxyalkanoate (PHA) Production
}

Tiago M. M. M. Amaro, Davide Rosa, Giuseppe Comi and Lucilla lacumin*

Dipartimento di Scienze Agroalimentari, Ambientali e Animali, Università degli Studi di Udine, Udine, Italy

Plastic production and accumulation have devastating environmental effects, and consequently, the world is in need of environmentally friendly plastic substitutes. In this context, polyhydroxyalkanoates (PHAs) appear to be true alternatives to common

\section{OPEN ACCESS}

Edited by:

Peter Neubauer,

Technische Universität Berlin,

Germany

Reviewed by:

Shashi Kant Bhatia,

Korea University, South Korea

Christopher John Brigham,

Wentworth Institute of Technology,

United States

*Correspondence:

Lucilla lacumin

lucilla.iacumin@uniud.it

Specialty section:

This article was submitted to

Microbiotechnology, Ecotoxicology

and Bioremediation,

a section of the journal

Frontiers in Microbiology

Received: 18 December 2018

Accepted: 18 April 2019

Published: 09 May 2019

Citation:

Amaro TMMM, Rosa D, Comi G and lacumin L (2019) Prospects

for the Use of Whey

for Polyhydroxyalkanoate

(PHA) Production.

Front. Microbiol. 10:992.

doi: 10.3389/fmicb.2019.00992 plastics because they are biodegradable and biocompatible and can be biologically produced. Despite having comparable characteristics to common plastics, extensive PHA use is still hampered by its high production cost. PHAs are bacterial produced, and one of the major costs associated with their production derives from the carbon source used for bacterial fermentation. Thus, several industrial waste streams have been studied as candidate carbon sources for bacterial PHA production, including whey, an environmental contaminant by-product from the dairy industry. The use of whey for PHA production could transform PHA production into a less costly and more environmentally friendly process. However, the efficient use of whey as a carbon source for PHA production is still hindered by numerous issues, including whey pre-treatments and PHA producing strain choice. In this review, current knowledge on using whey for PHA production were summarized and new ways to overcome the challenges associated with this production process were proposed.

Keywords: whey, PHA, PHB, polyhydroxyalkanoate, bioplastics, environment, lactose

\section{INTRODUCTION}

The production of plastics, which are essential in all modern economies, is mostly achieved using fossil feedstocks that have high environmental implications. Moreover, worldwide production of plastics is drastically increasing (from 204 million tons in 2002 to 335 million tons in 2016) and is predicted to continue to increase (PlasticsEurope, 2015, 2017). Production of plastics has led to environmental concerns because plastics are not easily degradable and accumulate in the most varied environments (Barnes et al., 2009). Furthermore, despite remarkable efforts to increase recycling rates (in Europe, recycling increased by 79\% from 2006 to 2016), only 31.1\% of plastics were recycled in Europe in 2016. The remaining plastics are either disposed of in landfills $(27.3 \%)$ or used for energy recovery (production of electricity or as fuel for industrial 
processes) (41.6\%) (European Bioplastics) ${ }^{1}$. Consequently, these "conventional" plastics urgently need to be substituted by biologically produced and/or biodegradable plastics, which are called bioplastics. However, even though it is thought that approximately $85 \%$ of the plastic products can be substituted by bioplastics, only approximately $1 \%$ of the plastics produced in the world are bioplastics (European Bioplastics $)^{1}$. The production of bioplastics is predicted to grow, reaching a production of 2.44 million tons in 2022, of which only 1.086 million tons will be biodegradable (European Bioplastics) $^{2}$. However, this predicted increase is still unsatisfactory compared to the ever-growing global plastic demand (PlasticsEurope, 2017). Polyhydroxyalkanoates (PHAs) are biologically produced polyesters that have been considered extremely valuable alternatives to commonly used petroleumderived plastics (Madison and Huisman, 1999; Sudesh et al., 2000; Reddy et al., 2003; Verlinden et al., 2007; Akaraonye et al., 2010; Laycock et al., 2014; Li et al., 2016; MozejkoCiesielska and Kiewisz, 2016; Dietrich et al., 2017). These molecules accumulate in granules inside bacterial cells and, among other recently reported functions (Koller et al., 2017), provide carbon storage and reducing equivalents (Madison and Huisman, 1999). PHAs possess characteristics similar to common plastics and are biocompatible and biodegradable (Sudesh et al., 2000; Castilho et al., 2009; Laycock et al., 2014; Anjum et al., 2016). Therefore, PHAs are currently being industrially produced and have been used in a broad spectrum of end products, ranging from packaging to medical applications (Akaraonye et al., 2010; Carletto, 2014; Anjum et al., 2016; Mozejko-Ciesielska and Kiewisz, 2016; Dietrich et al., 2017).

Regardless of their excellent features and environmental advantages, more extensive use of PHAs is impaired by their high production costs (Byrom, 1987; Lee, 1996; Reddy et al., 2003; Koller et al., 2007a). One of the main factors contributing to these high costs is the use of expensive fermentation carbon sources, which have been shown to account for approximately $40 \%$ of the total PHA production costs (Choi and Lee, 1999; Kim, 2000). Thus, the use of waste materials as carbon sources for microbial-derived PHA production has been proposed in order to simultaneously reduce both PHA production and waste disposable costs (Choi and Lee, 1999; Kim, 2000; Koller et al., 2017; Nielsen et al., 2017). Several waste sources have been used to produce PHAs with relative success (Marshall et al., 2013; Nikodinovic-Runic et al., 2013; Anjum et al., 2016; Koller et al., 2017), including domestic wastewater (Carucci et al., 2001); food waste (Rhu et al., 2003); molasses (Albuquerque et al., 2007; Carvalho et al., 2014); olive oil mill effluents (Dionisi et al., 2005); palm oil mill effluents (Din et al., 2012); tomato cannery water (Liu et al., 2008); lignocellulosic biomass (Bhatia et al., 2019); coffee waste (Bhatia et al., 2018); starch (Bhatia et al., 2015); biodiesel industry waste (Kumar et al., 2014a; Sathiyanarayanan et al., 2017); used cooking oil

${ }^{1}$ European bioplastics: Available online at: https://www.european-bioplastics.org/ bioplastics/materials/; accessed on 20/02/2018.

${ }^{2}$ European bioplastics: Available online at: https://www.european-bioplastics.org/ market/; accessed on 20/02/2018.
(Ciesielski et al., 2015; Kourmentza et al., 2017); pea-shells (Patel et al., 2012; Kumar et al., 2014b); paper mill wastewater (Jiang et al., 2012); bio-oil from the fast-pyrolysis of chicken beds (Moita and Lemos, 2012); and cheese whey (Table 1).

Whey constitutes the main by-product of the dairy industry and is obtained by precipitation and removal of milk casein during cheese-making processes. Approximately 120 million tons of whey are produced annually throughout the world, of which only $50 \%$ are used for products used in human and animal feed (Nikodinovic-Runic et al., 2013). The remaining whey needs to be disposed of, which raises environmental concerns due to its relatively high organic load, as whey is mainly composed of lactose (39-60 g/L), fats $(0.99-10.58 \mathrm{~g} / \mathrm{L})$, proteins $(27-60 \mathrm{~g} / \mathrm{L})$, and mineral salts (4.6-8 g/L) (Prazeres et al., 2012; Colombo et al., 2016). From these cheese whey components, lactose is responsible for most of the biochemical oxygen demand of whey; therefore, it is essential to find a biotechnological use for lactose (Siso, 1996; Prazeres et al., 2012; Carvalho et al., 2013; Nikodinovic-Runic et al., 2013). The value of using whey lactose for PHA production is clear as it would dramatically decrease the costs of PHA production, without competing with the production of food for humans and simultaneously solving an environmental problem.

In this review, current knowledge on the use of cheese whey as a substrate for PHA production is summarized (Figure 1). Moreover, the problems and prospects of using whey as a substrate for industrial scale production of PHAs are pinpointed and discussed.

\section{MICROORGANISMS USED FOR THE PRODUCTION OF PHAS FROM WHEY}

Whey is a rich media that is clearly suited for microbial growth. However, finding microorganisms that efficiently produce PHAs when growing on whey has been shown to be extremely challenging. Unfortunately, some of the best-described PHAproducing microbial species have been shown to be unable to directly produce PHAs from whey. For instance, Cupriavidus necator [formerly known as Ralstonia eutropha, Wautersia eutropha, or Alcaligenes eutrophus (Vandamme and Coenye, 2004)] is capable of accumulating PHAs to up to $80 \%$ of its dry weight when growing on glucose (Ryu et al., 1997; Reinecke and Steinbüchel, 2008), but it is unable to efficiently grow and, consequently, produce PHAs on lactose, the predominant carbon source of whey (Povolo et al., 2010). Another example is the halophilic archaeal bacteria Haloferax mediterranei, which can accumulate PHAs to approximately $60 \%$ of its dry weight (Lillo and Rodriguez-Valera, 1990; Quillaguamán et al., 2010). Nevertheless, $H$. mediterranei, despite being capable of consuming lactose (Fernandez-Castillo et al., 1986), does not efficiently grow and produce PHA using this carbon source (Koller et al., 2007b). One exception is Alcaligenes latus, which is a known efficient PHA producer that can accumulate PHAs to up to $70 \%$ of its dry weight using diverse sugar sources ( $\mathrm{Yu}$ et al., 1999; Gahlawat and Srivastava, 2017). Recently, one study showed that Alcaligenes latus is able to convert whey lactose into 
TABLE 1 | Summary of the studies aimed at producing PHAs from whey divided by the whey pre-treatment type.

\begin{tabular}{|c|c|c|c|c|c|c|}
\hline Substrate & Type of culture & Microorganism & Culture method & Productivity $^{1}$ & Type of PHA & Reference \\
\hline \multirow{5}{*}{$\begin{array}{l}\text { Whey powder } \\
\text { supernatant }+ \\
\text { additives }\end{array}$} & Pure cultures & Alcaligenes latus & Batch culture & $0.11 \mathrm{~g} / \mathrm{L} / \mathrm{h}$ & $\mathrm{PHB}$ & Berwig et al., 2016 \\
\hline & Engineered cultures & $\begin{array}{l}\text { Engineered } \\
\text { Escherichia coli } \\
\text { with Alcaligenes } \\
\text { latus PHA } \\
\text { biosynthesis genes }\end{array}$ & Fed-batch culture & $\begin{array}{c}2.57 \mathrm{~g} / \mathrm{L} / \mathrm{h} ; 4.6 \mathrm{~g} / \mathrm{L} / \mathrm{h} ; \\
1.35 \mathrm{~g} / \mathrm{L} / \mathrm{h}\end{array}$ & $\mathrm{PHB}$ & $\begin{array}{l}\text { Ahn et al., 2000, 2001; } \\
\text { Park et al., } 2002\end{array}$ \\
\hline & & $\begin{array}{l}\text { Engineered } \\
\text { Escherichia coli } \\
\text { with Cupriavidus } \\
\text { necator PHA } \\
\text { biosynthesis genes }\end{array}$ & $\begin{array}{l}\text { Batch culture; } \\
\text { Fed-batch culture; } \\
\text { Fed-batch culture; } \\
\text { Fed-batch culture; } \\
\text { Fed-batch culture }\end{array}$ & $\begin{array}{c}5.2 \mathrm{~g} / \mathrm{L} / \mathrm{h} ; 1.408 \mathrm{~g} / \mathrm{L} / \mathrm{h} ; \\
0.90 \mathrm{~g} / \mathrm{L} / \mathrm{h} ; 0.57 \mathrm{~g} / \mathrm{L} / \mathrm{h} ; \\
0.33 \mathrm{~g} / \mathrm{L} / \mathrm{h}\end{array}$ & PHB & $\begin{array}{l}\text { Lee et al., 1997; Wong } \\
\text { and Lee, 1998; Kim, } \\
\text { 2000; Farinha, 2009; } \\
\text { Pais et al., } 2014\end{array}$ \\
\hline & & $\begin{array}{l}\text { Engineered } \\
\text { Escherichia coli } \\
\text { with Azotobacter } \\
\text { sp. PHA } \\
\text { biosynthesis genes }\end{array}$ & Fed-batch culture & $2.13 \mathrm{~g} / \mathrm{L} / \mathrm{h}$ & $\mathrm{PHB}$ & Nikel et al., 2006 \\
\hline & MMC & Undefined & Batch culture & $\begin{array}{l}0.0035 \mathrm{~g} / \mathrm{L} / \mathrm{h} \\
0.0226 \mathrm{~g} / \mathrm{L} / \mathrm{h}\end{array}$ & Not specified; PHB & $\begin{array}{l}\text { Bosco and Chiampo, } \\
\text { 2010; Carletto, } 2014\end{array}$ \\
\hline \multirow[t]{5}{*}{$\begin{array}{l}\text { Whey permeate + } \\
\text { additives }\end{array}$} & Pure cultures & $\begin{array}{l}\text { Sinorhizobium } \\
\text { meliloti; Bacillus } \\
\text { megaterium; } \\
\text { Bacillus spp.; } \\
\text { Sinorhizobium spp. }\end{array}$ & Batch culture & $0.005 \mathrm{~g} / \mathrm{L} / \mathrm{h}$ & $\mathrm{PHB}$ & $\begin{array}{l}\text { Povolo and Casella, } \\
2003\end{array}$ \\
\hline & & $\begin{array}{l}\text { Hydrogenophaga } \\
\text { pseudoflava }\end{array}$ & Batch culture & $\begin{array}{c}0.0039 \mathrm{~g} / \mathrm{L} / \mathrm{h} \\
0.05 \mathrm{~g} / \mathrm{L} / \mathrm{h}\end{array}$ & PHB;P-3(HB-CO-HV) & $\begin{array}{l}\text { Povolo and Casella, } \\
\text { 2003; Koller et al., } \\
\text { 2007b }\end{array}$ \\
\hline & & $\begin{array}{l}\text { Methylobacterium } \\
\text { sp. ZP24 }\end{array}$ & Batch culture & $0.02 \mathrm{~g} / \mathrm{L} / \mathrm{h}$ & $\mathrm{PHB}$ & Yellore and Desai, 1998 \\
\hline & Engineered cultures & $\begin{array}{l}\text { Engineered } \\
\text { Cupriavidus } \\
\text { necator with } \\
\text { Escherichia coli } \\
\text { lactose degradation } \\
\text { genes }\end{array}$ & Batch culture & $0.02 \mathrm{~g} / \mathrm{L} / \mathrm{h}$ & $\mathrm{PHB}$ & Povolo et al., 2010 \\
\hline & MMC & Undefined & Batch culture & $0.018 \mathrm{~g} / \mathrm{L} / \mathrm{h}$ & PHB & Carletto, 2014 \\
\hline \multirow[t]{5}{*}{$\begin{array}{l}\text { Hydrolyzed whey } \\
\text { permeate }+ \\
\text { additives }\end{array}$} & Pure cultures & $\begin{array}{l}\text { Pseudomonas } \\
\text { hydrogenovora }\end{array}$ & $\begin{array}{l}\text { Fed-batch culture; } \\
\text { Batch culture; } \\
\text { Fed-batch culture }\end{array}$ & $\begin{array}{c}\text { NS;0.03 g/L/h; } \\
0.04 \mathrm{~g} / \mathrm{L} / \mathrm{h}\end{array}$ & $\begin{array}{l}\text { PHB;PHB;P-3(HB-CO- } \\
\mathrm{HV}) ;\end{array}$ & $\begin{array}{l}\text { Koller et al., 2006, } \\
\text { 2007b, } 2008\end{array}$ \\
\hline & & $\begin{array}{l}\text { Haloferax } \\
\text { mediterranei }\end{array}$ & $\begin{array}{l}\text { Fed-batch culture; } \\
\text { Fed-batch culture; } \\
\text { Batch culture; } \\
\text { Fed-batch culture }\end{array}$ & $\begin{array}{c}\mathrm{NS} ; 0.14 \mathrm{~g} / \mathrm{L} / \mathrm{h} ; \\
0.05 \mathrm{~g} / \mathrm{L} / \mathrm{h} ; 0.148 \mathrm{~g} / \mathrm{L} / \mathrm{h}\end{array}$ & $\begin{array}{l}\text { P(3HB-co-3HV-co- } \\
4 \mathrm{HB}) ; \mathrm{P}-(3 \mathrm{HB}-\mathrm{CO}- \\
3 \mathrm{HV}) / \mathrm{P}(3 \mathrm{HB}-\mathrm{CO}-3 \mathrm{HV}- \\
\mathrm{CO}-4 \mathrm{HB}) ; \mathrm{P}-3(\mathrm{HB}-\mathrm{CO}- \\
\mathrm{HV}) ; \mathrm{P}-(3 \mathrm{HB}-\mathrm{CO}-3 \mathrm{HV})\end{array}$ & $\begin{array}{l}\text { Koller et al., 2006, } \\
2007 a, b ; \text { Koller, } 2015\end{array}$ \\
\hline & & $\begin{array}{l}\text { Cupriavidus } \\
\text { necator }\end{array}$ & Fed-batch culture & $0.17 \mathrm{~g} / \mathrm{L} / \mathrm{h}$ & P-(3HB-Co-3HV) & Marangoni et al., 2002 \\
\hline & & $\begin{array}{l}\text { Hydrogenophaga } \\
\text { pseudoflava }\end{array}$ & Batch culture & $0.012 \mathrm{~g} / \mathrm{L} / \mathrm{h}$ & P-3(HB-co-HV) & Koller et al., 2007b \\
\hline & Engineered cultures & $\begin{array}{l}\text { Engineered } \\
\text { Cupriavidus } \\
\text { necator with } \\
\text { Escherichia coli } \\
\text { lactose degradation } \\
\text { genes }\end{array}$ & Batch culture & $0.7 \mathrm{~g} / \mathrm{L} / \mathrm{h}$ & PHB & Povolo et al., 2010 \\
\hline \multirow[t]{2}{*}{ Whey + additives } & Pure cultures & $\begin{array}{l}\text { Bacillus cereus } \\
\text { PS-10 }\end{array}$ & Batch culture & NS & PHB & $\begin{array}{l}\text { Sharma and Bajaj, } \\
2015\end{array}$ \\
\hline & & $\begin{array}{l}\text { Pseudomonas } \\
\text { aeruginosa }\end{array}$ & Batch culture & $0.005 \mathrm{~g} / \mathrm{L} / \mathrm{h}$ & Diverse & $\begin{array}{l}\text { Singh and Mallick, } \\
2009\end{array}$ \\
\hline
\end{tabular}


TABLE 1 | Continued

\begin{tabular}{|c|c|c|c|c|c|c|}
\hline Substrate & Type of culture & Microorganism & Culture method & Productivity $^{1}$ & Type of PHA & Reference \\
\hline $\begin{array}{l}\text { Fermented whey } \\
\text { powder permeate }\end{array}$ & $\mathrm{MMC}$ & Undefined & $\begin{array}{l}\text { Fed-batch culture; } \\
\text { Fed-batch culture; } \\
\text { Batch culture; } \\
\text { Fed-Batch culture }\end{array}$ & $\begin{array}{c}0.56 \mathrm{~g} / \mathrm{L} / \mathrm{h} ; 0.25 \mathrm{~g} / \mathrm{L} / \mathrm{h} ; \\
0.80 \mathrm{Cmol} / \mathrm{Cmol} \\
0.204 \mathrm{~g} / \mathrm{L} / \mathrm{h}\end{array}$ & P-3(HB-CO-HV) & $\begin{array}{l}\text { Duque et al., 2014; } \\
\text { Oliveira et al., 2017; } \\
\text { Carvalho et al., 2018; } \\
\text { Domingos et al., 2018 }\end{array}$ \\
\hline \multirow[t]{3}{*}{$\begin{array}{l}\text { Whey supernatant } \\
+ \text { additives }\end{array}$} & Pure cultures & $\begin{array}{l}\text { Bacillus } \\
\text { megaterium }\end{array}$ & Batch culture & $0.06 \mathrm{~g} / \mathrm{L} / \mathrm{h}$ & $\mathrm{PHB}$ & Obruca et al., 2011 \\
\hline & & $\begin{array}{l}\text { Thermus } \\
\text { thermophilus HB8 }\end{array}$ & Batch culture & $0.023 \mathrm{~g} / \mathrm{L} / \mathrm{h}$ & Diverse & Pantazaki et al., 2009 \\
\hline & & $\begin{array}{l}\text { Methylobacterium } \\
\text { sp. ZP24 }\end{array}$ & Batch culture & $0.12 \mathrm{~g} / \mathrm{L} / \mathrm{h}$ & PHB & Yellore and Desai, 1998 \\
\hline $\begin{array}{l}\text { Fermented whey } \\
\text { supernatant }\end{array}$ & $\mathrm{MMC}$ & Undefined & Fed-batch culture & $\begin{array}{l}0.42 \mathrm{mg} \mathrm{COD}_{\mathrm{PHA}} \\
\mathrm{mg} / \mathrm{COD}_{\mathrm{SS}}\end{array}$ & $\mathrm{PHB} / \mathrm{P}-3(\mathrm{HB}-\mathrm{CO}-\mathrm{HV})$ & Colombo et al., 2016 \\
\hline $\begin{array}{l}\text { Fermented whey } \\
\text { powder }\end{array}$ & $\mathrm{MMC}$ & Undefined & Fed-batch culture & $\begin{array}{l}0.68 \mathrm{gCOD} / \mathrm{gCOD} ; 0.6 \\
\mathrm{Cmol} \text { PHA/Cmol Substrate }\end{array}$ & P-3(HB-Co-HV) & $\begin{array}{l}\text { Gouveia et al., 2017; } \\
\text { Fradinho et al., } 2019\end{array}$ \\
\hline $\begin{array}{l}\text { Fermented whey } \\
\text { permeate }+ \\
\text { additives }\end{array}$ & MMC & Undefined & Fed-batch culture & $\begin{array}{c}0.59 \\
g_{\text {gCODPHA }} / g C O D_{\text {Substrate }}\end{array}$ & P-3(HB-CO-HV) & $\begin{array}{l}\text { Janarthanan et al., } \\
2016\end{array}$ \\
\hline $\begin{array}{l}\text { Hydrolyzed whey + } \\
\text { additives }\end{array}$ & Pure cultures & $\begin{array}{l}\text { Halomonas } \\
\text { halophila }\end{array}$ & Batch cultures & $0.05 \mathrm{~g} / \mathrm{L} / \mathrm{h}$ & $\mathrm{PHB}$ & Kucera et al., 2018 \\
\hline $\begin{array}{l}\text { Whey/whey } \\
\text { supernatant }\end{array}$ & Pure cultures & $\begin{array}{l}\text { Methylobacterium } \\
\text { sp. ZP24 }\end{array}$ & Fed-batch culture & $0.08 \mathrm{~g} / \mathrm{L} / \mathrm{h}$ & PHB & Nath et al., 2008 \\
\hline $\begin{array}{l}\text { Hydrolyzed whey } \\
\text { powder } \\
\text { supernatant + } \\
\text { additives }\end{array}$ & Pure cultures & $\begin{array}{l}\text { Haloferax } \\
\text { mediterranei }\end{array}$ & Batch culture & $0.16 \mathrm{~g} / \mathrm{L} / \mathrm{h}$ & P(3HB-co-3HV) & Pais et al., 2016 \\
\hline $\begin{array}{l}\text { Fermented whey } \\
\text { powder } \\
\text { supernatant }+ \\
\text { additives }\end{array}$ & MMC & Undefined & Batch culture & $\begin{array}{c}0.46 \\
\mathrm{COD}_{\mathrm{PHA}} / \mathrm{gCOD} \text { Substrat }\end{array}$ & $\mathrm{P}(3 \mathrm{HB}-\mathrm{CO}-3 \mathrm{HV})$ & Valentino et al., 2015 \\
\hline $\begin{array}{l}\text { Whey powder + } \\
\text { additives }\end{array}$ & Engineered cultures & $\begin{array}{l}\text { Engineered } \\
\text { Escherichia coli } \\
\text { with Cupriavidus } \\
\text { necator PHA } \\
\text { biosynthesis genes }\end{array}$ & Fed-batch culture & $1.4 \mathrm{~g} / \mathrm{L} / \mathrm{h}$ & $\mathrm{PHB}$ & Wong and Lee, 1998 \\
\hline
\end{tabular}

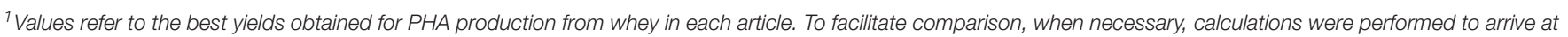
values in $\mathrm{g} / \mathrm{L} / \mathrm{h}$. Otherwise, we report the values as presented in the cited work. NS, not specified.

PHA (0.11 $\mathrm{g} \mathrm{L}^{-1} \mathrm{~h}^{-1}$ ) (Berwig et al., 2016) (Table 1). While the PHA yield obtained is not comparable to the yields obtained when Alcaligenus latus is grown in other carbon sources, more studies should be conducted to assess the full potential of using A. latus to produce PHAs from whey (Berwig et al., 2016).

The low capacity of highly PHA-producing microorganisms to produce PHA from whey lactose was, in some cases, bypassed by chemically or enzymatically converting whey lactose into glucose and galactose prior to fermentation. Using this hydrolyzed whey lactose, high PHA producers, such as $C$. necator and $H$. mediterranei, were shown to be able to produce PHAs (Marangoni et al., 2002; Pais et al., 2016) (Table 1). However, the steps required to convert whey lactose into glucose and galactose add to the final cost of PHAs and thus, from an industrial point of view, should be avoided. These conversion steps have, in fact, already been avoided by deploying genetic engineering techniques. For instance, Escherichia coli cells capable of consuming lactose were modified to express PHA biosynthesis genes from high PHA-producing microorganisms (Ahn et al., 2000, 2001). Alternatively, high producing strains were engineered to express lactose degradation genes (Povolo et al., 2010) (Table 1). While genetic engineering is a highly versatile and promising tool for enhancing PHA production from whey, the use of genetically engineered strains requires more controlled production plants. In fact, benefits and ethics aside, the wide application of genetic modified microorganisms (GMMs) in scientific research lab and biotechnology industry raises the concern of the accidental release of genetically modified species (or strains) into the environment and subsequent gene transfer to microorganisms/non-microorganisms host. In view of this, it has been considered necessary by biosafety regulations of individual countries to regulate their use avoiding any potential risks they may pose. The order requires notification, risk evaluation and approval of work with GMMs and approval of laboratories or plants where work with GMOs is to take place. Laboratories for working with GMMs are classified in four classes each with specific regulations with regard to containment, organization of the laboratories and the laboratory areas, plans for execution of the work, technical facilities, internal supervision, and control (Council Directive 98/81/EC of 26 


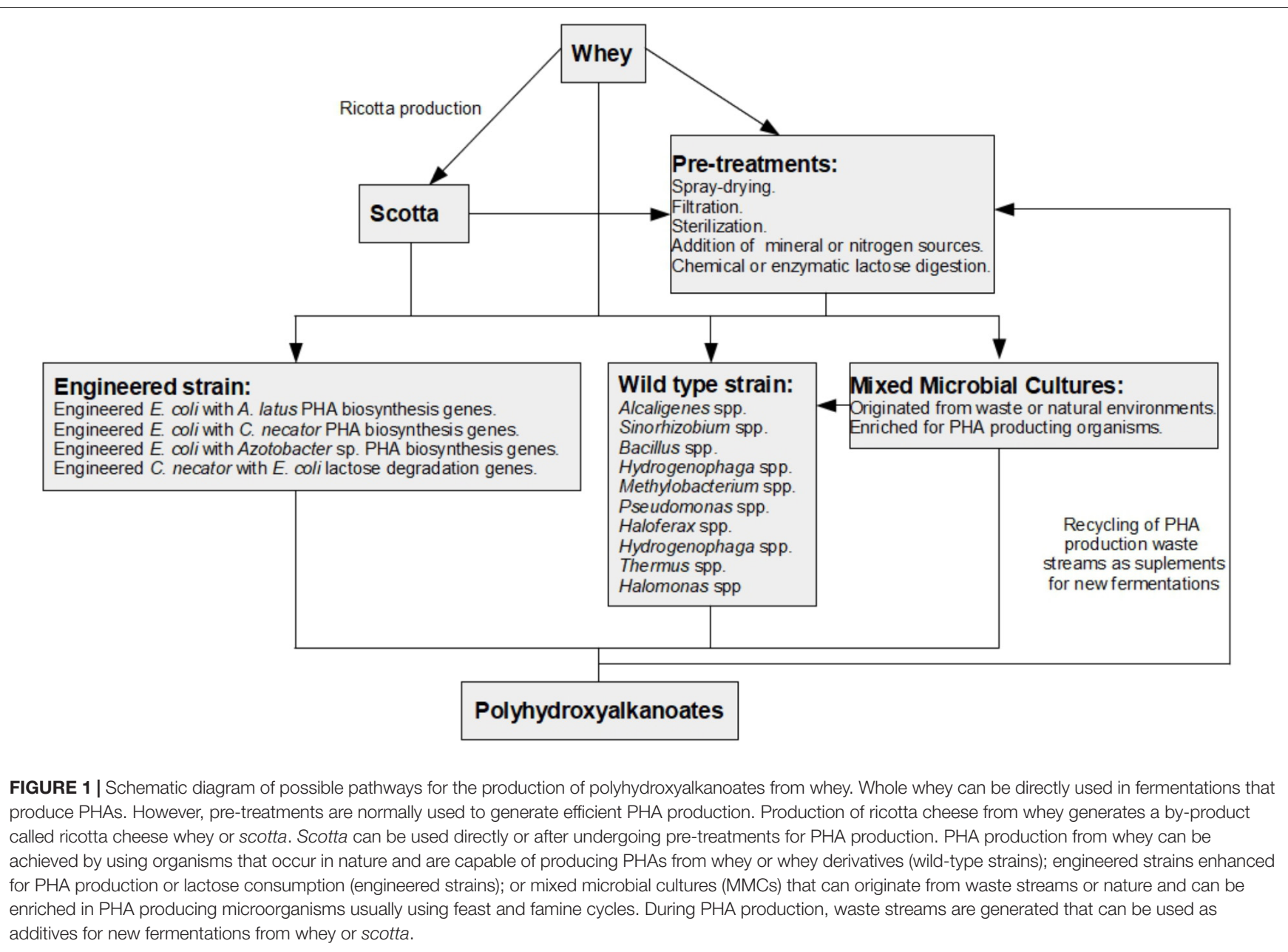

October 1998 amending Directive 90/219/EEC on the contained use of genetically modified micro-organisms) (Devos et al., 2008; Guo et al., 2019). Therefore, biotechnology laboratories and industries require biosafety measures designed to protect their staff, the population, and the environment, which may be exposed to hazardous microorganisms and materials, as well as qualified staff, increasing the management costs of the plants and consequently the PHA production costs.

Considering all these observations, it is clear that an extremely valuable option for achieving economically competitive production of PHAs from whey would be to discover wildtype bacterial species that can directly produce high levels of PHA from whey lactose. However, currently, besides the abovementioned A. latus (Berwig et al., 2016), only a few wildtype microbes have been shown to be able to directly produce PHA from whey lactose and without exceptional PHA yields (Figure 1 and Table 1). Other microbes have been shown to produce PHAs from lactose-based media, including Bacillus sp. (Thirumala et al., 2010) and Enterobacter cloacae SU-1 (Samrot et al., 2011). Nevertheless, it remains unclear whether these microbes can use whey-derived lactose for PHA production.

Another option for whey-based PHA production that has recently received great attention is the use of mixed microbial cultures (MMCs) instead of single microbial strains (Colombo et al., 2016). While MMCs have been associated with lower yields of PHA production, they do not require sterile conditions and are able to adapt to changing industrial waste complex substrates (Reis et al., 2011; Colombo et al., 2016). MMCs have been used to directly produce PHAs from cheese whey lactose or after a first digestion of lactose by a different MMC (Carletto, 2014; Duque et al., 2014; Valentino et al., 2015; Colombo et al., 2016) (Table 1). MMCs are obtained from waste sources and are normally subsequently enriched for PHA production using feast and famine cycles designed to increase the presence of strains that are capable of creating PHA-based carbon reservoirs (Nielsen et al., 2017). Despite their great flexibility and cost advantages, using an unknown microbial community to produce PHAs can raise questions regarding the production efficiency, consistency of the polymer characteristics and biocompatibility when PHAs are to be used in medical applications. Nevertheless, the use of MMCs opens interesting prospects for identifying new PHAproducing microorganisms from these communities. Studies on MMCs showed that they consist of diverse bacterial genera, which change according to the tested fermentation carbon source (Janarthanan et al., 2016); however, a study in which single organisms were isolated for PHA production from whey has not, 
to our knowledge, been performed to date. Another possibility that would include the advantages of both MMCs and single strain fermentation would be to use MMCs to convert whey lactose into other carbon sources (such as organic acids) and then use a high PHA producer single strain to convert these organic acids into PHAs. This option has been proposed (Graziani and Fornasiero, 2007), but it has not yet been attempted for the production of PHAs from whey.

\section{WHEY PRE-TREATMENTS}

Whey is a substrate that has numerous difficulties for direct use in PHA production. First, whey has been reported to have a low C-N rate, which greatly hinders PHA production (Bosco and Chiampo, 2010). Additionally, as previously discussed, lactose is not the preferred sugar of PHA-producing strains. Moreover, whey is a complex, unsterile and often variable by-product, and thus, its direct application in both lab-scale experiments and industrial production pipelines results in an abundance of other difficulties. Therefore, many studies that report PHA production from whey have actually been performed on whey derivatives that have undergone a series of pretreatments (Figure 1 and Table 1) instead of whey itself. One of these derivatives is whey powder, which is diluted in water prior to fermentation to obtain a specific lactose concentration. Whey powder, normally produced by spray-drying, allows longer storage of whey as well as avoids seasonal variations of this byproduct (Písecký, 2005; Chegini and Taheri, 2013). Nevertheless, a spray-drying step will increase costs in a PHA production pipeline. Thus, while acknowledging the possible consistencybased reasoning behind using whey powder for screening and optimizing PHA production, it remains unclear whether fermentations using whey are comparable to those performed with a whey powder.

The other extensively used pre-treatment of whey, regardless of whether it is a liquid or powder, is the removal of the majority of its proteins and other solids by ultrafiltration, creating a whey permeate that retains most of the whey lactose (Koller et al., 2007b). In addition to ultrafiltration, this protein removal is also commonly obtained by acidifying whey to a $\mathrm{pH}$ close to 4 followed by a heat treatment, centrifugation and filtration, generating a so-called whey supernatant (Pantazaki et al., 2009). These whey permeates or supernatants are easier to work with, as they are sterile, homogeneous and clear solutions; however, their use increases the production costs. Moreover, it was shown that whole whey and whey supernatant, used as carbon sources in a complex mineral media, led to different biomass growth and PHA accumulation in Methylobacterium sp. ZP24 (Yellore and Desai, 1998). Therefore, attention should be paid when extrapolating results obtained from whey permeates or supernatants to whole whey.

Other types of additives, which are routinely used when dealing with whey in PHA production studies, consist of minerals and nitrogen sources (Table 1). The use of these additives could probably be avoided by using whole whey instead of whey permeates or supernatants. However, for some studies, it remains to be seen whether the used microorganisms are capable of accumulating high amounts of PHAs using whey without additives, which would be ideal for industrial production. For Bacillus megaterium, the addition of salts $\left(\left(\mathrm{NH}_{4}\right)_{2} \mathrm{SO}_{4}\right.$, $5 \mathrm{~g} \mathrm{~L}^{-1} ; \mathrm{Na}_{2} \mathrm{HPO}_{4}, 2.5 \mathrm{~g} \mathrm{~L}^{-1} ; \mathrm{KH}_{2} \mathrm{PO}_{4}, 2.5 \mathrm{~g} \mathrm{~L}^{-1} ; \mathrm{MgSO}_{4}$, $0.2 \mathrm{~g} \mathrm{~L}^{-1}$; and $\mathrm{MnSO}_{4}, 0.01 \mathrm{~g} \mathrm{~L}^{-1}$ ) to whey supernatant increased its biomass and PHA production by almost 10 times (Obruca et al., 2011). Therefore, if any addition should be made to whey for enhanced PHA production, it would be interesting to explore the use of other inexpensive waste products as whey additives; this point will be discussed subsequently in this paper.

Whole whey should be more widely used to study PHA production. However, the use of whole whey raises important experimental challenges, including sterility issues. These issues are not as relevant when using MMCs; however, for single cultures, sterilization is crucial (Koller et al., 2011). Sterilization of whole whey with high temperatures cannot be performed as total whey protein will precipitate, and filtration is difficult due to the high quantity of suspended solids present in whey. Low-temperature pasteurization could be used, but it normally involves several cycles of heat and cold treatments that result in expensive and timeconsuming processes (Ghaly and Kamal, 2004). Moreover, pasteurization does not assure full sterilization, which can lead to sterility problems during fermentation processes. Therefore, alternative sterilization techniques, such as the use of ultraviolet radiation or high temperature-short time pasteurization, have been proposed to be used prior to fermentation with pure strains in whole whey (Morr, 1987; Ghaly and Kamal, 2004). Furthermore, the use of antibiotics has also been attempted to solve these issues. Vancomycin was shown to reduce Bacillus cereus contamination in Hydrogenophaga pseudoflava PHA production from whey without significantly affecting the PHA production efficiency (Koller et al., 2011). Another problem that arises by using untreated whole whey is the high lactose concentration. It was shown that the whey lactose concentration was crucial for biomass and PHA production by B. megaterium CCM 2037. In fact, while growing on whey supernatant with a lactose concentration of $40 \mathrm{~g} / \mathrm{L}$, this strain grew to approximately $1.5 \mathrm{~g} / \mathrm{L}$ biomass and produced less than $0.5 \mathrm{~g} / \mathrm{L}$ PHAs; when grown in a diluted whey supernatant with a concentration of $20 \mathrm{~g} / \mathrm{L}$, the production values increased to $2.51 \mathrm{~g} / \mathrm{L}$ biomass and produced $0.79 \mathrm{~g} / \mathrm{L}$ PHAs (Obruca et al., 2011).

In addition to these whey pre-treatments, for specific microorganisms, as previously mentioned, transformation of whey lactose into galactose and glucose needs to be performed prior to fermentation (Table 1). Some authors have avoided lactose hydrolysis by using media that mimics hydrolyzed whey containing galactose and glucose as carbon sources (Wallner et al., 2001; Koller et al., 2011). The majority of the remaining studies proceeded to hydrolysis using $\beta$-galactosidase enzymes and showed that microbes were able to use glucose and galactose originating from enzymatic hydrolysis of cheese whey lactose 
(Marangoni et al., 2002; Koller et al., 2005, 2007a,b, 2008; Koller, 2015). However, the use of enzymatic hydrolysis greatly increases the costs of a possible PHA production plan. Thus, it is necessary to highlight that it has also been shown that chemical lactose hydrolysis using $\mathrm{HCl}$ resulted in whey lactose hydrolysates that could be used for microbial production of PHAs (Pais et al., 2016; Kucera et al., 2018). Nevertheless, preferably, these treatments should be avoided by finding either wild-type microorganisms that accumulate high levels of PHAs using lactose as a carbon source or microorganisms that convert lactose into more widely used carbon sources for PHA production.

The use of MMCs avoids most of these problems, as, in theory, a community is able to thrive and evolve in diverse environments and still produce PHAs. However, this hypothesis has not been widely tested, as most studies used whey powder derivatives to test MMC production of PHAs (Table 1). In addition to whey powder, whey permeate has also been used (Carletto, 2014) as well as the supernatant of whey, which has been subjected to a first fermentation to transform whey lactose (Colombo et al., 2016). Interestingly, the use of these whey supernatants yielded more PHA production than those obtained by using whey powder and whey permeates (Colombo et al., 2016). These results led us to believe that the use of MMCs may be the correct approach for producing PHAs from whole whey. However, these results also suggest that there are considerable PHA productivity differences when using diverse whey derivatives. Therefore, MMCs should be tested for PHA production using whole whey.

Finally, most of the current knowledge on using whey for PHA production is based on studies that use whey derivatives to ensure experimental consistency and ease (Table 1). However, it is now time to use whole whey, as this is crucial for obtaining a comprehensive view of the actual feasibility of using whey for PHA production in an industrially viable manner.

\section{ALTERNATIVE ROUTES TO IMPROVE PHA PRODUCTION FROM WHEY}

In this review, the focus is on two important factors that need to be taken into consideration when aiming at achieving an economically viable production of PHA from cheese whey: microorganism choice and whey pre-treatment requirements. While acknowledging that not all factors can be reviewed here, it is necessary to mention, nonetheless, that some other important aspects need to be considered to achieve efficient production of PHAs from whey.

\section{Recycling in PHA Production From Whey}

As discussed in the previous sections, to achieve efficient production of PHAs from whey, it is necessary to use several additives to whey. Thus, it would be extremely interesting if these additives could originate from other waste streams. Fermentations of enzymatically digested whey lactose for PHA production by $H$. mediterranei were used to test the feasibility of using recycling waste streams in future PHA production pipelines (Koller, 2015). H. mediterranei is an extreme halophile, and as a consequence, its use has the advantages of reducing sterilization costs and enabling easier PHA extraction methods based on differential osmotic pressures (Koller et al., 2007b). Nevertheless, fermentations for PHA production using $H$. mediterranei generate vast quantities of highly saline waste streams. Therefore, authors have assessed the possibility of using these obtained waste streams in subsequent fermentations. Despite the low yields obtained, the re-use of waste streams allowed PHA production, opening exciting prospects for further studies on re-using waste streams in PHA production processes (Koller, 2015). Another interesting prospect that should be explored and that, to our knowledge, is still undescribed is to use these streams in other biotechnological production processes. Therefore, studies that investigate the use of recycling waste streams during PHA production from whey would be of extreme significance when aiming to create added value using environmentally friendly industrial processes.

To achieve optimized PHA production from whey, it has been shown that the use of additives, such as salts or nitrogen sources, is required. Thus, and as mentioned previously, it would be of extreme value if these additives could derive from other food wastes. While this type of additive source for PHA production from whey remains greatly unexplored, whey has already been used as an additive for PHA production using waste frying oils. Protease hydrolyzed whey has been shown to work as a complex nitrogen source to enhance PHA production from waste frying oils using $C$. necator by approximately $40 \%$ (Obruca et al., 2014). Therefore, the mixing of waste sources opens nearly endless possibilities to enhance the efficiency of PHA production without the need for costly additives. In addition to other waste streams, low cost additives could also be tested for PHA production enhancements. The addition of $1 \%$ ethanol as an exogenous stress factor on cheese whey, for instance, was shown to enhance $B$. megaterium PHA production by approximately 40\% (Obruca et al., 2011). The use of ethanol or other stress factors, such as PHA production enhancers, should definitively be taken into account when optimizing PHA production from cheese whey.

As previously stated, whole whey is a complex and rich media that can create obstacles to sterilization, fermentation efficiency and PHA extraction methods. Thus, whey pre-treatments are normally required and have an impact on production costs. It would be helpful if whole whey could be first used in a different biotechnological process, followed by the use of the residues of this process for PHA production. Whole whey is commonly used in ricotta cheese-making, which generates a by-product called ricotta cheese whey or scotta (Sansonetti et al., 2009; Bergamaschi and Bittante, 2018). Scotta retains most of the lactose from whey but has a highly reduced protein content (De Giorgi et al., 2018), which could initially inhibit microbial growth and interfere with PHA extraction processes. The production of scotta mostly occurs in Italy, where it accounted for approximately one million tons in 2009 and has already been tested as a carbon source for 
several biotechnological processes, such as the production of bioethanol (Zoppellari and Bardi, 2013), biodiesel (Carota et al., 2017), probiotics (Lavari et al., 2014), lactic acid (Secchi et al., 2012), and lactobionic acid (De Giorgi et al., 2018). It has also been shown that scotta can possibly be used to produce PHA via fermentation by MMCs. MMCs were demonstrated to be able to produce PHA from scotta without any pre-treatment other than a filtration step and achieve PHA productivities of up to $1.65 \mathrm{~g} / \mathrm{L}$ (Carletto, 2014). Thus, scotta production could prove to be a productive and extremely unexplored middle step in the efficient transformation of cheese whey into PHAs. Nonetheless, further studies are needed to determine the full potential of using scotta in industrial scale PHA production.

\section{PHA Purification From Whey}

Another possible problem that can arise from using whole whey for microbial PHA production is connected to the extraction and purification of PHAs. Initially, there were mainly two strategies to extract PHAs from bacterial cells. The first strategy used solvents, such as chloroform and methanol, taking advantage of the solubility of PHA in chloroform and its insolubility in methanol (Byrom, 1987; Suriyamongkol et al., 2007). With these solvent-based methods, high yields of PHA extraction were obtained (greater than 90\%). However, the use of solvents makes these processes economically as well as environmentally unappealing (Byrom, 1987). The second strategy involved the use of enzymes and detergents that remove cellular components while leaving PHAs intact (Suriyamongkol et al., 2007). These strategies are more environmentally friendly but normally result in lower PHA yields and, when using enzymes, also high costs (Mozejko-Ciesielska and Kiewisz, 2016). Several new solvents and methods are being tested to substitute for the more widely used extraction methods (Madkour et al., 2013), including the prospect of creating microbial strains that are capable of secreting PHAs (Sabirova et al., 2006). Despite interest in this strategy, it has not been followed up, with the exception of a study that showed partial PHA secretion from engineered E. coli cells (Rahman et al., 2013). Nevertheless, for PHAs production from whey, there has not been a deep investigation into alternative and cheaper PHA extraction methods. The only alternative environmentally friendly method tested for PHA extraction from whey works solely with one microorganism because it takes advantage of the inner high osmotic pressure of $H$. mediterranei cells to easily achieve cell disruption (Koller, 2015). Moreover, as previously stated, most studies used whey permeates and supernatants as substrates for PHA production. It, therefore, remains to be shown whether the extraction methods used result in comparable PHA recovery yields and purities when using whole whey, which contains large amounts of proteins and lipids and creates another level of complexity for PHA extraction processes.

\section{Type of PHAs Produced From Whey}

The types of hydroxyalkanoate (HA) monomers that are being produced constitute another factor that needs to be carefully considered when analyzing PHA production costs, as there have been more than $150 \mathrm{HA}$ monomer types identified (Reis et al., 2011). PHAs with different monomer compositions and structures present diverse economically important properties that affect their market value. The most common HA monomer produced by bacteria is 3hydroxybutyrate $(3 \mathrm{HB})$, and PHAs composed of only this monomer have economically interesting properties. Nonetheless, PHAs that incorporate other monomers different from $3 \mathrm{HB}$ in their chains, such as 3-hydroxyvalerate (3HV), have generally improved market desired properties (Reis et al., 2011; MozejkoCiesielska and Kiewisz, 2016; Albuquerque and Malafaia, 2018). Therefore, it is important to consider the PHA monomer composition while optimizing PHA production from whey as, recently, different whey pre-treatments were shown to lead to the production of different types of PHAs. Cheese whey fermented by autochthonous cheese lactic acid bacteria and subsequently used for PHA production by an MMC led to the production of PHAs composed solely of $3 \mathrm{HB}$ monomers. On the other hand, MMCs produced PHA co-polymers composed of both $3 \mathrm{HB}(60 \%)$ and $3 \mathrm{HV}$ (40\%) monomers when using cheese whey fermented by inoculated sporogeneous acidogenic bacteria. These results are explained by the presence of several $\mathrm{HB}$ precursors (including lactic, butyric, and acetic acids) in fermented cheese whey obtained by the action of autochthonous cheese lactic acid bacteria, in contrast to the presence of $\mathrm{HV}$ precursors (for instance, propionic and valeric acids) in cheese whey fermented by inoculated sporogeneous acidogenic bacteria (Colombo et al., 2016). These results demonstrate that whey is a suitable carbon source for the production of high-value PHAs and also the importance of testing whole whey for PHA production because changes in fermentation substrates influence not only the PHA yield but also its monomer composition.

\section{CONCLUSION}

Economically and environmentally viable production of bioplastics is required to solve the environmental problems that arise from the production and accumulation of conventional plastics. PHAs could play an important role in this bioplastic solution because they have market-desired properties and can be biologically produced from inexpensive waste substrates, such as whey. However, there are still numerous challenges that need to be overcome to achieve efficient production of PHAs from whey. In this work, the studies that describe PHA production from whey focusing on whey pre-treatments and the choice of producing microorganisms have been summarized (Table 1). Our current knowledge on PHA production from whey provides clear indications that producing PHA from whey is possible and can be achieved using diverse strategies. Notwithstanding, this review also highlights that there is a shortage of studies that aim at using whey to produce PHAs at a large scale and consider the costs and environmental impacts of future industrial producing 
plants. Therefore, this study could motivate and guide future studies focusing on obtaining economically viable production of PHAs from whey.

\section{AUTHOR CONTRIBUTIONS}

TA was responsible for data collection, wrote the first draft of the manuscript, and revised the article. DR and GC revised the manuscript. LI was responsible for the conception and design of the manuscript and revised it critically.

\section{REFERENCES}

Ahn, W. S., Park, S. J., and Lee, S. Y. (2000). Production of poly (3hydroxybutyrate) by fed-batch culture of recombinant Escherichia coli with a highly concentrated whey solution. Appl. Environ. Microbiol. 66, 3624-3627. doi: 10.1128/aem.66.8.3624-3627.2000

Ahn, W. S., Park, S. J., and Lee, S. Y. (2001). Production of poly (3hydroxybutyrate) from whey by cell recycle fed-batch culture of recombinant Escherichia coli. Biotechnol. Lett. 23, 235-240.

Akaraonye, E., Keshavarz, T., and Roy, I. (2010). Production of polyhydroxyalkanoates: the future green materials of choice. J. Chem. Technol. Biotechnol. 85, 732-743. doi: 10.1002/jctb.2392

Albuquerque, M. G. E., Eiroa, M., Torres, C., Nunes, B. R., and Reis, M. A. M. (2007). Strategies for the development of a side stream process for polyhydroxyalkanoate (PHA) production from sugar cane molasses. J. Biotechnol. 130, 411-421. doi: 10.1016/j.jbiotec.2007.05.011

Albuquerque, P. B. S., and Malafaia, C. B. (2018). Perspectives on the production, structural characteristics and potential applications of bioplastics derived from polyhydroxyalkanoates. Int. J. Biol. Macromol. 107, 615-625. doi: 10.1016/j. ijbiomac.2017.09.026

Anjum, A., Zuber, M., Zia, K. M., Noreen, A., Anjum, M. N., and Tabasum, S. (2016). Microbial production of polyhydroxyalkanoates (PHAs) and its copolymers: a review of recent advancements. Int. J. Biol. Macromol. 89, 161-174. doi: 10.1016/j.ijbiomac.2016.04.069

Barnes, D. K. A., Galgani, F., Thompson, R. C., and Barlaz, M. (2009). Accumulation and fragmentation of plastic debris in global environments. Philos. Trans. R. Soc. B Biol. Sci. 364, 1985-1998. doi: 10.1098/rstb.2008.0205

Bergamaschi, M., and Bittante, G. (2018). From milk to cheese: evolution of flavor fingerprint of milk, cream, curd, whey, ricotta, scotta, and ripened cheese obtained during summer Alpine pasture. J. Dairy Sci. 101, 3918-3934. doi: $10.3168 /$ jds.2017-13573

Berwig, K. H., Baldasso, C., and Dettmer, A. (2016). Production and characterization of poly(3-hydroxybutyrate) generated by Alcaligenes latus using lactose and whey after acid protein precipitation process. Bioresour. Technol. 218, 31-37. doi: 10.1016/j.biortech.2016.06.067

Bhatia, S. K., Gurav, R., Choi, T.-R., Jung, H.-R., Yang, S.-Y., Moon, Y.-M., et al. (2019). Bioconversion of plant biomass hydrolysare into bioplastic (polyhydroxyalkanoates) using Ralstonia eutropha 5119. Bioresour. Technol. 271, 306-315. doi: 10.1016/j.biortech.2018.09.122

Bhatia, S. K., Kim, J.-H., Kim, M.-S., Kim, J., Wong, J. W., Hong, Y. G., et al. (2018). Production of (3-hydroxybutyrate-co-3-hydroxyhexanoate) copolymer from coffee waste oil using engineered Ralstonia eutropha. Bioprocess Biosyst. Eng. 41, 229-235. doi: 10.1007/s00449-017-1861-4

Bhatia, S. K., Shim, Y.-H., Jeon, J.-M., Brigham, C. J., Kim, Y.-H., Kim, H.-J., et al. (2015). Starch based polyhydroxybutyrate production in engineered Escherichia coli. Bioprocess Biosyst. Eng. 38, 1479-1484. doi: 10.1007/s00449-015-1390-y

Bosco, F., and Chiampo, F. (2010). Production of polyhydroxyalkanoates (PHAs) using milk whey and dairy wastewater activated sludge Production of bioplastics using dairy residues. J. Biosci. Bioeng. 109, 418-421. doi: 10.1016/ j.jbiosc.2009.10.012

Byrom, D. (1987). Polymer synthesis by microorganisms: technology and economics. Trends Biotechnol. 5, 246-250. doi: 10.1016/0167-7799(87)90100-4

\section{FUNDING}

The authors thank the Friuli Venezia Giulia Region, who supported the work (Research Grant under the HEaD Higher Education and Development Program).

\section{ACKNOWLEDGMENTS}

We would like to thank all of our colleagues from the University of Udine for their continuous help and support.

Carletto, A. (2014). Studio Della Produzione di Poliidrossialcanoati da Siero di Latte. Ph.D. thesis, Politecnico di Torino, Turin

Carota, E., Crognale, S., D'Annibale, S., Gallo, A. M., Stazi, S. R., and Petruccioli, M. (2017). A sustainable use of Ricotta Cheese Whey for microbial biodiesel production. Sci. Total Environ. 584-585, 554-560. doi: 10.1016/j.scitotenv.2017. 01.068

Carucci, A., Dionisi, D., Majone, M., Rolle, E., and Smurra, P. (2001). Aerobic storage by activated sludge on real wastewater. Water Res. 35, 3833-3844. doi: 10.1016/s0043-1354(01)00108-7

Carvalho, F., Prazeres, A. R., and Rivas, J. (2013). Cheese whey wastewater: characterization and treatment. Sci. Total Environ. 445-446, 385-396. doi: 10. 1016/j.scitotenv.2012.12.038

Carvalho, G., Oehmen, A., Albuquerque, M. G. E., and Reis, M. A. M. (2014). The relationship between mixed microbial culture composition and PHA production performance from fermented molasses. New Biotechnol. 31, $257-$ 263. doi: 10.1016/j.nbt.2013.08.010

Carvalho, G., Pedras, I., Karst, S. M., Oliveira, C. S. S., Duque, A. F., Nielsen, P. H., et al. (2018). Functional redundancy ensures performance robustness in 3-stage PHA-producing mixed cultures under variable feed operation. New Biotechnol. 40(Part B), 207-217. doi: 10.1016/j.nbt.2017.08.007

Castilho, L. R., Mitchell, D. A., and Freire, D. M. G. (2009). Production of polyhydroxyalkanoates (PHAs) from waste materials and by-products by submerged and solid-state fermentation. Bioresour. Technol. 100, 5996-6009. doi: 10.1016/j.biortech.2009.03.088

Chegini, G., and Taheri, M. (2013). Whey powder: process technology and physical properties: a review. Middle East J. Sci. Res. 13, 1377-1387.

Choi, J., and Lee, S. Y. (1999). Factors affecting the economics of polyhydroxyalkanoate production by bacterial fermentation. Appl. Microbiol. Biotechnol. 51, 13-21. doi: 10.1007/s002530051357

Ciesielski, S., Mozejko, J., and Pisutpaisal, N. (2015). Plant oils as promising substrates for polyhydroxyalkanoates production. J. Clean. Prod. 106, 408-421. doi: 10.1016/j.jclepro.2014.09.040

Colombo, B., Sciarria, T. P., Reis, M., Scaglia, B., and Adani, F. (2016). Polyhydroxyalkanoates (PHAs) production from fermented cheese whey by using a mixed microbial culture. Bioresour. Technol. 218, 692-699. doi: 10.1016/ j.biortech.2016.07.024

De Giorgi, S., Raddadi, N., Fabbri, A., Toschi, T. G., and Fava, F. (2018). Potential use of ricotta cheese whey for the production of lactobionic acid by Pseudomonas taetrolens strains. New Biotechnol. 42, 71-76. doi: 10.1016/j.nbt. 2018.02.010

Devos, Y., Maeseele, P., Reheul, D., Van Speybroeck, L., and De Waele, D. (2008). Ethics in the societal debate on genetically modified organisms: a (Re)quest for sense and sensibility. J. Agric. Environ. Ethics 1, 29-61. doi: 10.1007/s10806007-9057-6

Dietrich, K., Durmont, M., Del Rio, F., and Orsat, V. (2017). Producing PHAs in the bioeconomy - Towards a sustainable bioplastic. Sustain. Prod. Consumpt. 9, 58-70. doi: 10.1016/j.spc.2016.09.001

Din, M. F., Mohanadoss, P., Ujang, Z., van Loosdrecht, M., Yunus, S. M., Chelliapan, S., et al. (2012). Development of Bio-PORec system for polyhydroxyalkanoates (PHA) production and its storage in mixed cultures of palm oil mill effluent (POME). Bioresour. Technol. 124, 208-216. doi: 10.1016/ j.biortech.2012.08.036 
Dionisi, D., Carucci, G., Petrangeli Papini, M., Riccardi, C., Majone, M., and Carrasco, F. (2005). Olive oil mill effluents as a feedstock for production of biodegradable polymers. Water Res. 39, 2076-2084. doi: 10.1016/j.watres.2005. 03.011

Domingos, J. M. B., Puccio, S., Martinez, G. A., Amaral, N., Reis, M. A. M., Bandini, S., et al. (2018). Cheese whey integrated valorisation: production, concentration and exploitation of carboxylic acids for the production of polyhydroxyalkanoates by a fed-batch culture. Chem. Eng. J. 336, 47-53. doi: 10.1016/j.cej.2017.11.024

Duque, A. F., Oliveira, C. S. S., Carmo, I. T. D., Gouveia, A. R., Pardelha, F., Ramos, A. M., et al. (2014). Response of a three-stage process for PHA production by mixed microbial cultures to feedstock shift: impact on polymer composition. New Biotechnol. 31, 276-288. doi: 10.1016/j.nbt.2013. 10.010

Farinha, I. S. (2009). Optimization of Bioplastics Production from Cheese Whey. Ph.D. thesis, Faculdade de Ciências e Tecnologia da Universidade Nova de Lisboa, Costa da Caparica.

Fernandez-Castillo, R., Rodriguez-Valera, F., Gonzalez-Ramos, J., and RuizBerraquero, F. (1986). Accumulation of Poly ( $\beta$-Hydroxybutyrate) by Halobacteria. Appl. Environ. Microbiol. 51, 214-216.

Fradinho, J. C., Oehmen, A., and Reis, M. A. M. (2019). Improving polyhydroxyalkanoates production in phototrophic mixed cultures by optimizing accumulator reactor operating conditions. Int. J. Biol. Macromol. 126, 1085-1092. doi: 10.1016/j.ijbiomac.2018.12.270

Gahlawat, G., and Srivastava, A. K. (2017). Model-based nutrient feeding strategies for the increased production of polyhydroxybutyrate (PHB) by Alcaligenes latus. Appl. Biochem. Biotechnol. 183, 530-542. doi: 10.1007/s12010-017-2482-8

Ghaly, A. E., and Kamal, M. A. (2004). Submerged yeast fermentation of acid cheese whey for protein production and pollution potential reduction. Water Res. 38, 631-644. doi: 10.1016/j.watres.2003.10.019

Gouveia, A. R., Freitas, E. B., Galinha, C. F., Carvalho, G., Duque, A. F., and Reis, M. A. M. (2017). Dynamic change of $\mathrm{pH}$ in acidogenic fermentation of cheese whey towards polyhydroxyalkanoates production: impact on performance and microbial population. New Biotechnol. 37, 108-116. doi: 10.1016/j.nbt.2016.07.001

Graziani, M., and Fornasiero, P. (2007). Renewable Resources and Renewable Energy: A Global Challenge. Boca Raton, FL: CRC Press.

Guo, M., Ye, J., Gao, D., Xu, N., and Yang, J. (2019). Agrobacterium-mediated horizontal gene transfer: mechanism, biotechnological application, potential risk and forestalling strategy. Biotechnol. Adv. 37, 259-270. doi: 10.1016/j. biotechadv.2018.12.008

Janarthanan, O. M., Laycock, B., Montano-Herrera, L., Lu, Y., Arcos-Hernandez, M. V., Werker, A., et al. (2016). Fluxes in PHA-storing microbial communities during enrichment and biopolymer accumulation processes. New Biotechnol. 33, 61-72. doi: 10.1016/j.nbt.2015.07.007

Jiang, Y., Marang, L., Tamis, J., van Loosdrecht, M. C. M., Dijkman, H., and Kleerebezem, R. (2012). Waste to resource: converting paper mill wastewater to bioplastic. Water Res. 46, 5517-5530. doi: 10.1016/j.watres.2012.07.028

Kim, B. S. (2000). Production of poly(3-hydroxybutyrate) from inexpensive substrates. Enzyme Microb. Technol. 27, 774-777. doi: 10.1016/s0141-0229(00) 00299-4

Koller, M. (2015). Recycling of waste streams of the biotechnological poly(hydroxyalkanoate) production by Haloferax mediterranei on whey. Int. J. Polym. Sci. 2015, 1-8. doi: 10.1155/2015/370164

Koller, M., Bona, R., Braunegg, G., Hermann, C., Horvat, P., Kroutil, M., et al. (2005). Production of polyhydroxyalkanoates from agricultural waste and surplus materials. Biomacromolecules 6, 561-565. doi: 10.1021/bm049478b

Koller, M., Bona, R., Chiellini, E., Fernandes, E. G., Horvat, P., Kutschera, C., et al. (2008). Polyhydroxyalkanoate production from whey by Pseudomonas hydrogenovora. Bioresour. Technol. 99, 4854-4863. doi: 10.1016/j.biortech. 2007.09.049

Koller, M., Hesse, P., Bona, R., and Kutschera, C. (2007a). Biosynthesis of high quality polyhydroxyalkanoate Co- and terpolyesters for potential medical application by the archaeon Haloferax mediterranei. Macromol. Symp. 253, 33-39. doi: 10.1002/masy.200750704

Koller, M., Hesse, P., Bona, R., Kutschera, C., Atlić, A., and Braunegg, G. (2007b). Potential of various archae- and eubacterial strains as industrial polyhydroxyalkanoate producers from whey. Macromol. Biosci. 7, 218-226. doi: 10.1002/mabi.200600211

Koller, M., Hesse, P., Salerno, A., Reiterer, A., and Braunegg, G. (2011). A viable antibiotic strategy against microbial contamination in biotechnological production of polyhydroxyalkanoates from surplus whey. Biomass Bioenergy 35 , 748-753. doi: 10.1016/j.biombioe.2010.10.008

Koller, M., Horvat, P., Hesse, P., Bona, R., Kutschera, C., Atlic, A., et al. (2006). Assessment of formal and low structured kinetic modeling of polyhydroxyalkanoate synthesis from complex substrates. Bioprocess Biosyst. Eng. 29, 367-377. doi: 10.1007/s00449-006-0084-x

Koller, M., Maršálek, L., de Sousa Dias, M. M., and Braunegg, G. (2017). Producing microbial polyhydroxyalkanoate (PHA) biopolyesters in a sustainable manner. New Biotechnol. 37, 24-38. doi: 10.1016/j.nbt.2016.05.001

Kourmentza, C., Costa, J., Azevedo, Z., Servin, C., Grandfils, C., De Freitas, V., et al. (2017). Burkholderia thailandensis as a microbial cell factory for the bioconversion of used cooking oil to polyhydroxyalkanoates and rhamnolipids. Bioresour. Technol. 247, 829-837. doi: 10.1016/j.biortech.2017.09.138

Kucera, D., Pernicová, I., Kovalcik, A., Koller, M., Mullerova, L., Sedlacek, P., et al. (2018). Characterization of the promising poly(3-hydroxybutyrate) producing halophilic bacterium Halomonas halophila. Bioresour. Technol. 256, 552-556. doi: 10.1016/j.biortech.2018.02.062

Kumar, P., Mehariya, S., Ray, S., Mishra, S., and Kalia, V. C. (2014a). Biodiesel industry waste: a potential source of bioenergy and biopolymers. Indian J. Microbiol. 55, 1-7. doi: 10.1016/j.jenvman.2015.07.046

Kumar, P., Singh, M., Mehariya, S., Patel, S. K. S., Lee, J.-K., and Kalia, V. C. (2014b). Ecobiotechnological approach for exploiting the abilities of Bacillus to produce co-polymer of polyhydroxyalkanoate. Indian J. Microbiol. 54, 151-157. doi: 10.1007/s12088-014-0457-9

Lavari, L., Páez, E., Cuatrin, A., Reiheimer, J., and Vinderola, G. (2014). Use of chesse whey for biomass production and spray drying of probiotic lactobacilli. J. Dairy Res. 81, 267-274. doi: 10.1017/S0022029914000156

Laycock, B., Halley, P., Pratt, S., Werker, A., and Lant, P. (2014). The chemomechanical properties of microbial polyhydroxyalkanoates. Prog. Polym. Sci. 39, 397-442. doi: 10.1016/j.progpolymsci.2013.06.008

Lee, S. Y. (1996). Plastic bacteria? Progress and prospects for polyhydroxyalkanoate production in bacteria. Trends Biotechnol. 14, 431-438. doi: 10.1016/01677799(96)10061-5

Lee, S. Y., Middelberg, A. P. J., and Lee, Y. K. (1997). Poly (3-hydroxybutyrate) production from whey using recombinant Escherichia coli. Biotechnol. Lett. 19, 1033-1035.

Li, Z., Yang, J., and Loh, X. J. (2016). Polyhydroxyalkanoates: opening doors for a sustainable future. NPG Asia Mater. 8:e265. doi: 10.1038/am.2016.48

Lillo, J. G., and Rodriguez-Valera, F. (1990). Effects of culture conditions on poly(beta-hydroxybutyric acid) production by Haloferax mediterranei. Appl. Environ. Microbiol. 56, 2517-2521.

Liu, H.-Y., Hall, P. V., Darby, J. L., Coats, E. R., Green, P. G., Thompson, D. E., et al. (2008). Production of polyhydroxyalkanoate during treatment of tomato cannery wastewater. Water Environ. Res. 80, 367-372. doi: 10.2175/ $106143007 \times 221535$

Madison, L. L., and Huisman, G. W. (1999). Metabolic engineering of poly(3hydroxyalkanoates): from DNA to plastic. Microbiol. Mol. Biol. Rev. 63, 21-53.

Madkour, M. H., Heinrich, D., Alghamdi, M. A., Shabbaj, I. I., and Steinbüchel, A. (2013). PHA recovery from biomass. Biomacromolecules 14, 2963-2972. doi: $10.1021 / \mathrm{bm} 4010244$

Marangoni, C., Furigo, A., and De Aragão, G. M. F. (2002). Production of poly(3hydroxybutyrate-co-3-hydroxyvalerate) by Ralstonia eutropha in whey and inverted sugar with propionic acid feeding. Process Biochem. 38, 137-141. doi: 10.1016/j.biortech.2018.02.056

Marshall, C. W., LaBelle, E., and May, H. D. (2013). Production of fuels and chemicals from waste by microbiomes. Curr. Opin. Biotechnol. 24, 391-397. doi: 10.1016/j.copbio.2013.03.016

Moita, R., and Lemos, P. C. (2012). Biopolymers production from mixed cultures and pyrolysis by-products. J. Biotechnol. 157, 578-583. doi: 10.1016/j.jbiotec. 2011.09.021

Morr, C. V. (1987). Effect of HTST pasteurization of milk, cheese whey and cheese whey UF retentate upon the composition, physicochemical and functional properties of whey protein concentrates. J. Food Sci. 52, 312-317. doi: 10.1111/ j.1365-2621.1987.tb06601.x 
Mozejko-Ciesielska, J., and Kiewisz, R. (2016). Bacterial polyhydroxyalkanoates: still fabulous? Microbiol. Res. 192, 271-282. doi: 10.1016/j.micres.2016.07.010

Nath, A., Dixit, M., Bandiya, A., Chavda, S., and Desai, A. J. (2008). Enhanced PHB production and scale up studies using cheese whey in fed batch culture of Methylobacterium sp. ZP24. Bioresour. Technol. 99, 5749-5755. doi: 10.1016/j. biortech.2007.10.017

Nielsen, C., Rahman, A., Rehman, A. U., Walsh, M. K., and Miller, C. D. (2017). Food waste conversion to microbial polyhydroxyalkanoates. Microb. Biotechnol. 10, 1338-1352. doi: 10.1111/1751-7915.12776

Nikel, P. I., Almeida, A., Melillo, E. C., Galvagno, M. A., and Pettinari, M. J. (2006). New recombinant Escherichia coli strain tailored for the production of poly(3hydroxybutyrate) from agroindustrial by-products. Appl. Environ. Microbiol. 72, 3949-3954. doi: 10.1128/aem.00044-06

Nikodinovic-Runic, J., Guzik, M., Kenny, S. T., Babu, R., Werker, A., and Connor, K. E. O. (2013). Carbon-rich wastes as feedstocks for biodegradable polymer (polyhydroxyalkanoate) production using bacteria. Adv. Appl. Microbiol. 84, 139-200. doi: 10.1016/B978-0-12-407673-0.00004-7

Obruca, S., Benesova, P., Oborna, J., and Marova, I. (2014). Application of protease-hydrolyzed whey as a complex nitrogen source to increase poly(3hydroxybutyrate) production from oils by Cupriavidus necator. Biotechnol. Lett. 36, 775-781. doi: 10.1007/s10529-013-1407-z

Obruca, S., Marova, I., Melusova, S., and Mravcova, L. (2011). Production of polyhydroxyalkanoates from cheese whey employing Bacillus megaterium CCM 2037. Ann. Microbiol. 61, 947-953. doi: 10.1007/s13213-011-0218-5

Oliveira, C. S. S., Silva, C. E., Carvalho, G., and Reis, M. A. (2017). Strategies for efficiently selecting PHA producing mixed microbial cultures using complex feedstocks: feast and famine regime and uncoupled carbon and nitrogen availabilities. New Biotechnol. 37, 67-69. doi: 10.1016/j.nbt.2016.10.008

Pais, J., Farinha, I., Freitas, F., Serafim, L. S., Martínez, V., Martínez, J. C., et al. (2014). Improvement on the yield of polyhydroxyalkanoates production from cheese whey by a recombinant Escherichia coli strain using the proton suicide methodology. Enzyme Microb. Technol. 55, 151-158. doi: 10.1016/j.enzmictec. 2013.11.004

Pais, J., Serafim, L. S., Freitas, F., and Reis, M. A. M. (2016). Conversion of cheese whey into poly(3-hydroxybutyrate-co-3-hydroxyvalerate) by Haloferax mediterranei. New Biotechnol. 33, 224-230. doi: 10.1016/j.nbt.2015.06.001

Pantazaki, A. A., Papaneophytou, C. P., Pritsa, A. G., Liakopoulou-kyriakides, M., and Kyriakidis, D. A. (2009). Production of polyhydroxyalkanoates from whey by Thermus thermophilus HB8. Process Biochem. 44, 847-853. doi: 10.1016/j. procbio.2009.04.002

Park, S. J., Park, J. P., and Lee, S. Y. (2002). Production of poly(3-hydroxybutyrate) from whey by fed-batch culture of recombinant Escherichia coli in a pilot-scale fermenter. Appl. Environ. Microbiol. 63, 4795-4796.

Patel, S. K. S., Singh, M., Kumar, P., Purohit, H. J., and Kalia, V. C. (2012). Exploitation of defined bacterial cultures for production of hydrogen and polyhydroxybutyrate from pea-shells. Biomass Bioenergy 36, 218-225. doi: 10. 1016/j.biortech.2014.11.029

Písecký, J. (2005). Spray drying in the cheese industry. Int. Dairy J. 15, 531-536. doi: 10.1016/j.idairyj.2004.11.010

PlasticsEurope (2015). Plastics - the Facts 2014/2015 an analysis of European Plastics Production, Demand and Waste Data. Available at: https://www.plasticseurope.orgapplicationfiles5515/168992202014plastics_the _facts_PubFeb2015.pdf (accessed February 5, 2018).

PlasticsEurope (2017). Plastics - the Facts 2017 An analysis of European Plastics Production, Demand and Waste Data. Available at: https://www.plasticseurope.org/application/files/5715/1717/4180/Plastics_the _facts_2017_FINAL_for_website_one_page.pdf (accessed February 5, 2018).

Povolo, S., and Casella, S. (2003). Bacterial production of PHA from lactose and cheese whey permeate. Macromol. Symp. 197, 1-9. doi: 10.1016/j.biortech.2010. 05.029

Povolo, S., Toffano, P., Basaglia, M., and Casella, S. (2010). Polyhydroxyalkanoates production by engineered Cupriavidus necator from waste material containing lactose. Bioresour. Technol. 101, 7902-7907. doi: 10.1016/j.biortech.2010.05.029

Prazeres, A. R., Carvalho, F., and Rivas, J. (2012). Cheese whey management: a review. J. Environ. Manage. 110, 48-68. doi: 10.1016/j.jenvman.2012.05.018

Quillaguamán, J., Guzmán, H., Van-Thuoc, D., and Hatti-Kaul, R. (2010). Synthesis and production of polyhydroxyalkanoates by halophiles: current potential and future prospects. Appl. Microbiol. Biotechnol. 85, 1687-1696. doi: 10.1007/ s00253-009-2397-6

Rahman, A., Linton, E., Hatch, A. D., Sims, R. C., and Miller, C. D. (2013). Secretion of polyhydroxybutyrate in Escherichia coli using a synthetic biological engineering approach. J. Biol. Eng. 7:24. doi: 10.1186/1754-1611-7-24

Reddy, C. S. K., Ghai, R., Rashmi, and Kalia, V. C. (2003). Polyhydroxyalkanoates: an overview. Bioresour. Technol. 87, 137-146. doi: 10.1016/s0960-8524(02) 00212-2

Reinecke, F., and Steinbüchel, A. (2008). Ralstonia eutropha strain H16 as model organism for PHA metabolism and for biotechnological production of technically interesting biopolymers. J. Mol. Microbiol. Biotechnol. 16, 91-108. doi: $10.1159 / 000142897$

Reis, M., Albuquerque, M., Villano, M., and Majone, M. (2011). Mixed Culture Processes for Polyhydroxyalkanoate Production from Agro-Industrial Surplus/Wastes as Feedstocks. Amsterdam: Elsevier B.V.

Rhu, D. H., Lee, W. H., Kim, J. Y., and Choi, E. (2003). Polyhydroxyalkanoate (PHA) production from waste. Water Sci. Technol. 48, 221-228. doi: 10.2166/ wst.2003.0472

Ryu, H. W., Hahn, S. K., Chang, Y. K., and Chang, H. N. (1997). Production of poly(3-hydroxybutyrate) by high cell density fed-batch culture of Alcaligenes eutrophus with phosphate limitation. Biotechnol. Bioeng. 55, 28-32. doi: 10. 1002/(sici)1097-0290(19970705)55:1<28::aid-bit4>3.3.co;2-7

Sabirova, J. S., Ferrer, M., Lunsdorf, H., Wray, V., Kalscheuer, R., Steinbüchel, A., et al. (2006). Mutation in a "tesB-like" hydroxyacyl-coenzyme A-specific thioesterase gene causes hyperproduction of extracellular polyhydroxyalkanoates by Alcanivorax borkumensis SK2. J. Bacteriol. 188, 8452-8459. doi: 10.1128/jb.01321-06

Samrot, A. V., Avinesh, R. B., Sukeetha, S. D., and Senthilkumar, P. (2011). Accumulation of poly [(R)-3-hydroxyalkanoates] in Enterobacter cloacae SU1 during growth with two different carbon sources in batch culture. Appl. Biochem. Biotechnol. 163, 195-203. doi: 10.1007/s12010-010-9028-7

Sansonetti, S., Curcio, S., Calabro, V., and Iorio, G. (2009). Bio-ethanol production by fermentation of ricotta cheese whey as an effective alternative non-vegetable source. Biomass Bioenergy 33, 1687-1692. doi: 10.1016/j.biombioe.2009.09.002

Sathiyanarayanan, G., Bhatia, S. K., Song, H.-S., Jeon, J.-M., Kim, J., Lee, Y. K., et al. (2017). Production and characterization of medium-chainlenght polyhydroxyalkanoate copolymer from Arctic psychrotrophic bacterium Pseudomonas sp. PAMC 28620. Int. J. Biol. Macromol. 97, 710-720. doi: 10.1016/ j.ijbiomac.2017.01.053

Secchi, N., Giunta, D., Pretti, L., García, M. R., Roggio, T., Mannazzu, I., et al. (2012). Bioconversion of ovine scotta into lactic acid with pure and mixed cultures of lactic acid bacteria. J. Ind. Microbiol. Biotechnol. 39, 175-181. doi: 10.1007/s10295-011-1013-9

Sharma, P., and Bajaj, B. K. (2015). Cost-effective substrates for production of poly$\beta$-hydroxybutyrate by a newly isolated Bacillus cereus PS-10. J. Environ. Biol. 36, 1297-1304

Singh, A. K., and Mallick, N. (2009). Exploitation of inexpensive substrates for production of a novel SCL-LCL-PHA co-polymer by Pseudomonas aeruginosa MTCC 7925. J. Ind. Microbiol. Biotechnol. 36, 347-354. doi: 10.1007/s10295008-0503-x

Siso, M. I. G. (1996). The biotechnological utilization of cheese whey: a review. Bioresour. Technol. 57, 1-11. doi: 10.1016/0960-8524(96)00036-3

Sudesh, K., Abe, H., and Doi, Y. (2000). Synthesis, structure and properties of polyhydroxyalkanoates: biological polyesters. Prog. Polym. Sci. 25, 1503-1555. doi: 10.1016/s0079-6700(00)00035-6

Suriyamongkol, P., Weselake, R., Narine, S., Moloney, M., and Shah, S. (2007). Biotechnological approaches for the production of polyhydroxyalkanoates in microorganisms and plants - A review. Biotechnol. Adv. 2, 148-175. doi: 10. 1016/j.biotechadv.2006.11.007

Thirumala, M., Reddy, S. V., and Mahmood, S. K. (2010). Production and characterization of PHB from two novel strains of Bacillus spp. Isolated from soil and activated sludge. J. Ind. Microbiol. Biotechnol. 37, 271-278. doi: 10.1007/ s10295-009-0670-4

Valentino, F., Riccardi, C., Campanari, S., Pomata, D., and Majone, M. (2015). Fate of $\beta$-hexachlorocyclohexane in the mixed microbial cultures (MMCs) threestage polyhydroxyalkanoates (PHA) production process from cheese whey. Bioresour. Technol. 192, 304-311. doi: 10.1016/j.biortech.2015.05.083 
Vandamme, P., and Coenye, T. (2004). Taxonomy of the genus Cupriavidus: a tale of lost and found. Int. J. Syst. Evol. Microbiol. 54, 2285-2289. doi: 10.1099/ijs.0. 63247-0

Verlinden, R. A. J., Hill, D. J., Kenward, M. A., Williams, C. D., and Radecka, I. (2007). Bacterial synthesis of biodegradable polyhydroxyalkanoates. J. Appl. Microbiol. 102, 1437-1449. doi: 10.1111/j.1365-2672.2007.03335.x

Wallner, W., Haage, G., Bona, R., Schellauf, F., and Braunegg, G. (2001). "The production of poly-3-hydroxybutyrate-co-3- hydroxyvalerate with Pseudomonas cepacia ATCC 17759 on various carbon sources," in Biorelated Polymers: Sustainable Polymer Science and Technology, eds E. Chiellini, H. Gil, G. Braunegg, J. Buchert, P. Gatenholm, and M. van der Zee (Boston, MA: Springer), 139-145. doi: 10.1007/978-1-4757-3374-7_12

Wong, H. H., and Lee, S. Y. (1998). Poly-(3-hydroxybutyrate) production from whey by high-density cultivation of recombinant Escherichia coli. Appl. Microbiol. Biotechnol. 50, 30-33. doi: 10.1007/s002530051252

Yellore, V., and Desai, A. (1998). Production of poly-3-hydroxybutyrate from lactose and whey by Methylobacterium sp. ZP24. Lett. Appl. Microbiol. 26, 391-394. doi: 10.1046/j.1472-765x.1998.00362.x
Yu, P. H., Chua, H., Huang, A., and Ho, K. (1999). Conversion of industrial food wastes by Alcaligenes latus into polyhydroxyalkanoates. Appl. Biochem. Biotechnol. 78, 445-454. doi: 10.1385/abab:78:1$3: 445$

Zoppellari, F., and Bardi, L. (2013). Production of bioethanol from effluents of the dairy industry by Kluyveromyces marxianus. New Biotechnol. 6, 607-613. doi: 10.1016/j.nbt.2012.11.017

Conflict of Interest Statement: The authors declare that the research was conducted in the absence of any commercial or financial relationships that could be construed as a potential conflict of interest.

Copyright (C) 2019 Amaro, Rosa, Comi and Iacumin. This is an open-access article distributed under the terms of the Creative Commons Attribution License (CC BY). The use, distribution or reproduction in other forums is permitted, provided the original author(s) and the copyright owner(s) are credited and that the original publication in this journal is cited, in accordance with accepted academic practice. No use, distribution or reproduction is permitted which does not comply with these terms. 